\title{
EGY TANÁRI PÁLYAFUTÁS HÚSZ ÉVÉNEK ÜZENETEI
}

\section{FÜZI BEATRIX}

\author{
az Óbudai Egyetem Trefort Ágoston Mérnökpedagógiai Központjának \\ tanársegédje \\ fuzi.beatrix@tmpk.uni-obuda
}

\begin{abstract}
A tanár visszanéz és a pedagóguspályán eltöltött húsz esztendő tapasztalatait szellemi alkotásainak válogatásával, kötetbe rendezésével összegzi. Szabó László Tamás neve összeforrt a rejtett tanterv elméletével, de munkáinak most megjelent gyüjteménye az iskolával, a pedagógiával foglalkozók tág körének kínál olvasnivalót, köztük tanárjelölteknek, gyakorló pedagógusoknak és kutatóknak, a köz- és a felsőoktatással foglalkozóknak egyaránt.

Az írások összefüzésének elvei többek között az idörendiség és a különböző területeken folytatott tevékenységek bemutatása, de több gondolati szálon haladva is felfedezhetőek összefüggések. A tanulmányok között szerepelnek olyanok, melyek a nevelés legszemélyesebb, legbensőségesebb viszonyrendszerét érintik, és ennek megfelelően közvetlen közelről szólítják meg az olvasót. A szerző tapasztalatainak, kutatási eredményeinek kapcsán gondolkodásra késztetnek a diákokkal való bánásmód kulcselemeiről.

A válogatásban szereplő más írások a tanári és az iskolai munka általános és szervezeti szintjére összpontosítanak, érintve például a tanári önreflexió elméletét, az értékek nevelésben-oktatásban betöltött szerepét, az iskolai minőség és minősítés megállapításának problémáit. A könyvet alkotó munkák harmadik csoportja a nevelést tudományos igénnyel vizsgáló kutatások eredményeit, valamint a tanárképzés helyzetét - Európára is kitekintve - elemzi. E vállaltan eklektikus szerkezetú és múfajú kötetben egyes témakörök többször is felbukkannak - mint például az iskola, a tanár, a pedagógia implicit hatásmechanizmusai, az információs és tudás társadalmának iskolával, oktatással kapcsolatos dilemmái, valamint az interkulturális nevelés - és ezáltal hangsúlyosabbá válnak. A szerző szakmai és emberi hitvallását vállalva állást foglal és elköteleződik olyan vitás szakmai fogalmakkal, problémákkal kapcsolatban, mint a kompetencia, az interkulturalitás, az értékteremtés és átadás, vagy a konstruktivista szemlélet. Könyvével megfontolandó válaszokat kínál a pedagógia időszerü kérdéseire, melyek közül néhány az alábbiakban foglalható össze.
\end{abstract}

Kik rejtőznek a szerep-álarcok mögött? Felvállalható-e a személyiség és az érzelmek az iskolában? 
Az iskola szervezeti keretei, régóta őrzött szerepelvárásai és viselkedésmintái elfedik, hogy a nevelés, az oktatás emberek, egyéniségek együttmüködésében valósul meg. Újraértelmezésük talán azért tart soká, mert olyan konfliktusok kimondásától és megélésétől óvják meg a tanárt és a diákot egyaránt, melyek személyiségüket mélyen megrázhatnák. A látszat, mely alapján elég, ha az iskolában a tanár és diák csak intellektusával, szaktudásával, müveltségével van jelen, nem tartható. A szerző kutatásai arra világítanak rá, hogy az iskoláztatás során szerzett útravaló, melyet a személyiségek építő vagy romboló találkozása eredményez, legtöbbször feldolgozatlanul, a tudattalan szintjére süllyedve végzi pszichikus munkáját. A sikeres vagy kudarcos iskolai pályafutások okai legtöbbször e mélyrétegekben keresendők.

A személyiség és az érzelmek hogyan állíthatók az oktatási-nevelési célok szolgálatába?

A kötet egyik lényeges mondanivalója, hogy a tanítással foglalkozók számára megkerülhetetlen az iskolához kötődő érzelmek, élményvilágok megismerése, melyek kimondva vagy kimondatlanul befolyásolják az oktató-nevelö munka légkörét, hatékonyságát. Felelős tanári szerepmodellek kialakításakor, definiálásakor tisztán kell látni, hogy a pedagógus személyisége a diákokat kedvezőtlenül is érintheti. Az érzelmek tanári tevékenységbe való alkotó bekapcsolásának lehetőségeiröl több helyen is szó esik. Külön alfejezet tárgyalja az önreflexió elméletét, mely a tanár szakmai és személyiségfejlődésének útját önmagán belül határozza meg. Ide sorolhatóak azok a részek is, melyek hangsúlyozzák az oktatáselmélet diákközpontú megközelítésében rejlő lehetőségeket, és a tanulók teljesebb megismerésével, valamint a tudás feldolgozhatóvá, befogadhatóvá alakításában az érzelmek szerepével is foglalkoznak.

Hogyan alakul át a tanári mesterség?

A szerző tanári szakmát érintő mondanivalóját a szépirodalomból, a filozófiából és müvészetekből merített elemek is gazdagították, az olvasó örömére. A kötet üzenete alapján a tanári mesterség leginkább szolgálatként értelmezhető, mely alázatot és időről-időre önvizsgálatot követel művelöitől. A pedagógus központi szerepe módosul a tanuló munkájának, a tanulás katalizálásának, támogatásának irányába. A tanári tevékenységekben - a tervezéstől az értékelésig - a tudás befogadhatóvá alakításának és a tanuláshoz szükséges, felszabadult légkör megteremtésének képességét tartja legfontosabbnak. Ennek alapja, hogy a tanár képes nézőpontváltás eredményeként a tanuló szemével látni tantárgyát és önmagát.

Bár a tanár közel sem a tudás egyetlen forrása, a szerzö örömmel látná a jövőben, ha a pedagógus a tudás egyik tiszta forrásává válhatna. E tisztaság feltétele a személyes hitelesség, mely elfogadhatóvá, érvényessé teszi a tanulók számára a világból özönlő információ szelekcióját és rendszerezését. Így lehetséges, hogy a tartalmak elsajátítása mellett „,a tanuló számára szóló személyes jelentés” (81. o) is megfogalmazódjék. A tanári pálya azonban nem csak felelősség és erőfeszítés, jutalma a diákokkal megélhető szellemi intimitás, az „azonos hullámhossz”. 
Miben rejlik a jövő iskoláinak ereje?

Több gondolattal is alátámasztható, hogy a jelen és jövő iskoláit érő kihívásokban az iskola, mint a társadalom embernevelésre teremtett intézménye, mindenekelött a pedagógusokra, a bennük rejlő erőkre kell támaszkodjon. Egyrészt azért, mert ők a kimondott és kimondatlan elvárások elsődleges közvetítői. Másrészt, mert az önreflexió gyakorlása révén szakmájuk átfogóbb megismerésével, alapvető belátásokhoz jutva tantermi munkájuk színvonala jelentősen emelkedhet, tevékenységük iránti felelősségérzetük fokozódhat. Harmadrészt tanár és diák személyes találkozásának kiváltása valamely médium által, nem lehet szerencsés a szerző vélekedése szerint. A pedagógus feladata ugyanis a kultúraközvetítés, ami több puszta tájékoztatásnál: „értékes és érvényes tartalmak vonzó módon történő felajánlása, munkába vétele”. (87. o.) A kutatások és más tudományos munkák legfőbb értékméröjének is azt tekinti, hogy hozzájárulnak-e a mindennapi - és nem mindennapi - jelenségek mélyebb megismeréséhez és a gyakorlati tevékenység fejlesztéséhez.

Melyek az iskolát érintő kihívások és melyek lehetnek a célravezető stratégiák?

Az iskola világában is érezhetőek a globalizáció hatásai. Ennek jótékony és ártalmas voltáról sokféle nézet látott napvilágot, melyek ismerete arra ad lehetôséget a szerző szerint, hogy a globalizációból nyerhető értékeket, előnyöket az iskola okosan és alkotóan felhasználja. A kötet hangsúlyos témaköre az Európa szerte egyre több feszültséget jelentő probléma, az etnikai/nemzeti/nyelvi/vallási kisebbségek társadalmi integrációja, melynek megoldásában a társadalmak kiemelt szerepet szánnak az iskolának. A jelenleg ismert megoldások közül az interkulturális nevelés mellett érvel, amely a kultúrák sokszínüségének megőrzésére, az egyéni értékek és közösségi célok összehangolására támaszkodik. A súlyosbodó társadalmi feszültségeket érzékelve elutasítja a magánszféra térhódítási szándékait az oktatás területén, mert meglátása szerint az nem alkalmas arra, hogy érvényesítse a méltányosság és igazságosság nélkülözhetetlen értékeit, szemben az állami oktatásirányítással. A világméretủ gazdasági, ideológiai, társadalmi áramlatok következtében az iskola, az oktatás, a képzés most az érdeklődés homlokterében van. A kockázatokat mérlegelve, ugyanakkor a lehetőségeket megragadva a pedagógiát számottevően gazdagíthatja a jelenlegi helyzet.

Szabó László Tamás könyve - a címével ellentétben - elsősorban nem a múltról szól. Arra világít rá, hogy a tanár és kutató számára kitapinthatóak voltak a napjainkat és jövőnket meghatározó tendenciák. Az évekkel, évtizedekkel ezelött született írásokban olyan jelenségek ismerhetők fel és épülnek be a szerző kutatási felvetései közé, melyek napjainkra váltak igazán meghatározóvá az iskola világában. Így a könyv a változás irányaira érzékeny kutató fejlődésének és a pedagógia területén bejárt útjának, mások számára is hasznos, a jövőbe mutató összegzése.

Szabó László Tamás (2009): A tanár visszanéz. Új Mandátum Könyvkiadó, Budapest, 188 oldal 